\title{
CURRENT ISSUES IN
}

AGRICULTURAL ECONOMICS 


\section{CURRENT ISSUES IN ECONOMICS}

General Editor: David Greenaway, University of Nottingham

Current Issues in Microeconomics

Edited by John D. Hey

Current Issues in Macroeconomics

Edited by David Greenaway

Current Issues in Labour Economics

Edited by David Sapsford and Zafiris Tzannatos

Current Issues in International Monetary Economics

Edited by David T. Llewellyn and Chris Milner

Current Issues in Development Economics

Edited by V. N. Balasubramanyam and Sanjaya Lall

Current Issues in Financial and Monetary Economics

Edited by Kevin Dowd and Mervyn K. Lewis

Current Issues in Public Sector Economics

Edited by Peter M. Jackson

Current Issues in the Economics of Welfare

Edited by Nicholas Barr and David Whynes

Current Issues in Agricultural Economics

Edited by A. J. Rayner and David Colman

Forthcoming

Current Issues in Industrial Economics

Edited by John Cable 


\title{
Current Issues in \\ Agricultural Economics
}

Edited by

\author{
A. J. Rayner \\ Professor of Agricultural Economics \\ University of Nottingham
}

and

David Colman

Professor of Agricultural Economics

University of Manchester

Palgrave Macmillan UK 
ISBN 978-0-333-55695-5 ISBN 978-1-349-22698-6 (eBook)

DOI 10.1007/978-1-349-22698-6

Selection, editorial matter and Chapter 1 (C) A. J. Rayner and David Colman 1993

Individual chapters $@$ David Colman, Csaba Csáki, Tim Josling, W. Lesser and D. Lee, P. Midmore and D. A. Peel, A. J. Rayner and David Colman, A. J. Rayner, K. A. Ingersent and R. C. Hine, Terry Sicular, K. J. Thomson, L. Alan Winters 1993

All rights reserved. For information, write:

Scholarly and Reference Division,

St. Martin's Press, Inc., 175 Fifth Avenue,

New York, N.Y. 10010

First published in the United States of America in 1993

\section{ISBN 978-0-312-09091-3}

Library of Congress Cataloging-in-Publication Data

Current issues in agricultural economics / edited by A. J. Rayner and

David Colman.

p. cm. - (Current issues in economics)

Includes bibliographical references and index.

ISBN 978-0-312-09091-3

1. Agriculture and state-United States. 2. Agriculture-Economic

aspects-United States. 3. Produce trade-Government policy-United

States. 4. Agriculture and state. 5. Agriculture-Economic

aspects. 6. Produce trade-Government policy. 7. International

economic relations. I. Rayner, A. J. II. Colman, David.

III. Series.

HD1761.C87 1993

$338.1^{\prime} 0973-\mathrm{dc} 20$ 


\section{Contents}

LIST OF FIGURES vii

LIST OF TABLES viii

SERIES EDITOR'S PREFACE $\quad \mathrm{X}$

NOTES ON THE CONTRIBUTORS Xii

1 Current Issues in Agricultural Economics: Introduction and Overview

A.J. Rayner and David Colman 1

2 The Political Economy of Industrial Countries'

Agricultural Policies

L. Alan Winters

3 Agricultural Policy Reform in the USA and the EC Tim Josling

4 Agricultural Trade and the GATT

A.J. Rayner, K. A. Ingersent and R. C. Hine

5 Transformation of Agriculture in Central-Eastern Europe and the Soviet Union: Major Policy Issues and Perspectives

Csaba Czáki

6 The Quest for Sustained Growth in Chinese Agriculture Terry Sicular

7 Macroeconomics and the Agricultural Sector

P. Midmore and D. A. Peel 
8 Economics of Agricultural Research and Biotechnology $W$. Lesser and D. Lee

9 Environmental Economics and Agricultural Policy David Colman

10 Less Favoured Areas and Rural Decline K.J. Thomson

END-NOTES

BIBLIOGRAPHY 252

AUTHOR INDEX 272

SUBJECT INDEX 


\section{List of Figures}

3.1 Producer subsidy equivalents: selected products, EC, 1980-90

3.2 Producer subsidy equivalents: selected products, US, 1980-90

3.3 Total transfers to producers: selected commodities, EC, 1980-90

3.4 Total transfer to producers: selected commodities, US, 1980-90

3.5 Total economic loss due to policies: selected products, EC, $1980-90$

3.6 Total economic loss due to policies: selected products, US, $1980-90$

3.7 Unrequited cost of transfer: selected products, EC, 1980-90

3.8 Unrequited cost of transfer: selected products, US, 1980-90

7.1 The dollar/ECU exchange rate and per cent share of European Community export refunds in total EAGGF expenditure, 1978-89

8.1 Welfare gains from a research-induced supply function shift 


\section{List of Tables}

2.1. The declared objectives of agricultural policy in selected OECD countries

4.1 Benefits and costs of agricultural support, 1986/7 71

4.2 Extent of food market insulation 73

4.3 Welfare effects of liberalisation $\quad 76$

4.4 Net percentage PSEs, 1979-86 80

4.5 Main elements of initial negotiating positions, 1987-8 81

4.6 Main elements of post-Geneva accord long-term reform proposals (1989) $\quad 84$

4.7 Main elements of 'final' post-framework agreement reform proposals (late 1990) 86

5.1 Population and arable land resources of Eastern Europe and the USSR - 1988

5.2 Growth of gross agricultural output since 1970

$\begin{array}{ll}5.3 \text { Production of grains } & 100\end{array}$

5.4 Meat total production 101

5.5 Tractors used in agricultural production 102

5.6 Consumption of major food products, 1989

6.1 Growth in gross value of agricultural output 128

6.2 Survey statistics on collective (unified) production and planning activities

6.3 State procurement prices for selected farm products 134

6.4 Marketing and state procurement of grain 136

6.5 State investment in agricultural basic construction $\quad 142$

6.6 Statistics on agriculture investment by rural collectives and farm households

6.7 Statistics on the development of rural township and village enterprises

6.8 China's agricultural trade

7.1 The European agricultural budget and dollar/ECU exchange rate, 1978-89 
8.1 Average annual public agricultural research by region, 1961-85

8.2 Relative measures of agricultural research expenditures, GDP groupings, 1971-85

8.3 Estimates of private sector agricultural research expenditures, selected countries and years, 1985-9

8.4 Areas of near term applications in agriculture biotechnologies

8.5 Estimated 1985 worldwide R \& D expenditures on biotechnology and allocations to agriculture

10.1 Rural population change in the United Kingdom 


\section{Series Editor's Preface}

The Current Issues series has slightly unusual origins. Current Issues in International Trade, which Macmillan published in 1987 and which turned out to be the pilot for the series, was in fact 'conceived' in the Horton Hospital, Banbury, and 'delivered' (in the sense of completed) in the Hilton International in Nicosia! The reader may be struck by the thought that a more worthwhile and enjoyable production process would start and finish the other way around. I agree! Be that as it may, that is how the series started.

As I said in the Preface to Current Issues in International Trade the reason for its creation was the difficulty of finding suitable references on 'frontier' subjects for undergraduate students. Many of the issues which excite professional economists and which dominate the journal literature take quite a time to percolate down into texts; hence the need for a volume of Current Issues. The reception which Current Issues in International Trade received persuaded me that it may be worth doing something similar for the other subject areas we teach. Macmillan agreed with my judgement, hence the series. Thus each volume in this series is intended to take readers to the 'frontier' of the particular subject area. Each volume contains nine or ten essays, one of which provides a general overview whilst the remainder are devoted to current issues.

As series editor the main challenge I faced was finding suitable editors for each of the volumes - the best people are generally the busiest! I believe, however, that I have been fortunate in having such an impressive and experienced team of editors with the necessary skills and reputation to persuade first-class authors to participate. I would like to thank all of them for their cooperation and assistance in the development of the series. Like me, all of them will, I am sure, hope that this series provides a useful service to undergraduate and postgraduate students as well as faculty.

Current Issues in Agricultural Economics is the ninth in the series. Agricultural economics is one of the oldest branches of economic analysis. It is an area of considerable controversy - in industrialised, 
developing and erstwhile centrally planned economies. In this volume, Tony Rayner and David Colman have selected papers which have a topical and current policy focus, including the political economy of agricultural policy, agricultural policy reform in the US and the EC, agricultural trade and the GATT, transformation in Eastern Europe and in China, and environmental economics and policy. Certain complementary topics are also covered - macroeconomics and agriculture, agricultural research and biotechnology, and the rural economy and less favoured areas. These are interesting and exciting issues both to specialist students of agricultural economics as well as students in other sub-areas of the discipline. The editors have persuaded a group of distinguished authors from three different countries to contribute in order to give a balanced and international perspective to the subject matter. I am grateful that they have cooperated to produce such a useful addition to the series. 


\section{Notes on the Contributors}

David Colman is Professor of Agricultural Economics, University of Manchester.

Csaba Csáki is Professor of Agricultural Economics, Budapest University of Economic Sciences, and President of the International Association of Agricultural Economists.

R. C. Hine is Lecturer in Economics, University of Nottingham.

K. A. Ingersent is Senior Research Fellow in the Centre for Research in Economic Development and International Trade (CREDIT), University of Nottingham.

Tim Josling is Professor of Agricultural Economics, Food Research Institute, Stanford University.

D. Lee is Professor of Agricultural Economics, Cornell University.

W. Lesser is Professor of Agricultural Economics, Cornell University.

P. Midmore is Lecturer in Agricultural Economics, University College of Wales, Aberystwyth.

D. A. Peel is Professor of Economics, University College of Wales, Aberystwyth

A.J. Rayner is Professor of Agricultural Economics and Assistant Director of CREDIT, University of Nottingham.

Terry Sicular is Associate Professor of Economics, Harvard University.

K.J. Thomson is Professor of Rural Economics, University of Aberdeen.

L. Alan Winters is Professor of Economics, University of Birmingham. 